\title{
Electron microscopic study of a new microsporean Microsporidium epithelialis sp. n. infecting Tubifex sp. (Oligochaeta)
}

\author{
Mustapha Oumouna ${ }^{1}$, Mansour El-Matbouli ${ }^{1}$, Rudolf W. Hoffmann $^{1}$ and Georges Bouix ${ }^{2}$ \\ ${ }^{1}$ Institute of Zoology, Fish Biology and Fish Diseases, Kaulbachstraße 37, D-80539 Munich, Germany; \\ ${ }^{2}$ Université Montpellier II, Sciences et Techniques du Languedoc, UMR CNRS 219 Défense et Résistance chez les Invertébrés \\ Marins, C.P. 096, Place E. Bataillon, 34095 Montpellier Cedex 5, France
}

Key words: Microsporea, Actinosporea, ultrastructure, Oligochaeta, Tubificidae

\begin{abstract}
The cytology of a new microsporean parasite Microsporidium epithelialis sp. $\mathrm{n}$. from the intestinal epithelial cells of the freshwater oligochaete Tubifex sp. (Tubificidae) is described. The microsporean occurred together with an actinosporean of the genus Triactinomyxon, which was found between the epithelial cells. The merogonic and sporogonic stages (mature spores included) of the microsporean parasite are monokaryotic. An individual sporophorous vesicle surrounds each spore. The fixed and stained spore has an average dimension of 1.9-2.5 $\times$ 0.9-1.2 $\mu \mathrm{m}$. The spores are oval with a characteristic surface layer, showing ornamentation-like projections, which are in close contact to the exospore. A short polar filament forming three to four coils traverses the polaroplast with two lamellar layers. The ultrastructure and other characteristic features of this microsporean parasite are distinct from those of the microsporean species described so far from oligochaetes.
\end{abstract}

Microsporeans are obligate intracellular parasites infecting a wide range of host taxa and have been observed in different host-cell types (Canning 1990). Since microsporidia were assigned to the phylum Microspora Sprague, 1977, several different classifications have been presented. In the latest attempt by Sprague et al. (1992), the phylum Microspora was separated into two classes based on the presence or absence of a diplokaryon in the life cycle (classes Dihaplophasea and Haplophasea, respectively). Dihaplophasea contains species with meiosis in their life cycles, while species belonging to Haplophasea have been shown not to exhibit meiosis (Sprague et al. 1992).

Classification of the phylum Microspora is mainly based on ultrastructural characters. This has resulted in problems with old descriptions based on light microscopy. Therefore in many cases, new well-described species have to be placed in a genus with an inadequately described type species based on a few superficial characters.

The first microsporean species reported from oligochaetes was Myxocystis ciliata described from Limnodrilus claparedeanus by Mrázek (1897). Since then, many species have been described from oligochaete hosts (Table 1). They frequently infected the lymphocytes and were also found in coelomocytes, chloragogen cells, pharynx glands and male gonads.

In a survey study on the occurrence of actinosporean infection in oligochaetes, one tubificid was infected by actinosporean and microsporean parasites. The actinosporean infection was intercellular while the micro- sporean infection was intracellular in the gut epithelium of the worm.

In the present study, we investigate the morphological characteristics of different developmental stages of this new microsporean, temporarily named Microsporidium epithelialis.

\section{MATERIALS AND METHODS}

The tubificid worms Tubifex sp. were purchased from a commercial pet supplier and individually kept in well plates. Water was examined microscopically for the occurrence of waterborne actinosporean spores twice a week. Positive specimens were prepared for transmission electron microscopy (TEM). They were fixed in $2 \%$ glutaraldehyde for $2 \mathrm{~h}$. After washing in phosphate buffer ( $\mathrm{pH} 7.2$ ), the samples were post-fixed in $1 \%$ osmium tetroxide for $2 \mathrm{~h}$, washed, dehydrated in an ascending series of ethanol and embedded in Epon $^{\circledR}$. Semithin sections were stained with toluidine blue. Ultrathin sections were double-contrasted with uranyl acetate and lead citrate, and examined in a Zeiss EM 109 transmission electron microscope.

\section{RESULTS}

In the gut of one tubificid worm (Tubifex sp.), a double infection was observed with an actinosporean located between the epithelial cells and early developmental stages and mature spores of a species of the phylum Microspora located intracellularly in the intestinal epithelial cells (Figs. 1-3). The microsporean was not observed in squash preparations, therefore the description is restricted to the observation of semithin and ultrathin sections of infected tissues. 
Microsporidium epithelialis sp. $\mathrm{n}$.

Figs. 4-17

\section{Presporal stages}

The light and electron microscopic examination did not show hypertrophy of infected cells. Meronts surrounded by electron-dense trilaminar membrane were in direct contact with the host cytoplasm (Fig. 4). The nuclei of the host epithelial cells were not infected. The merogonial stages measured approximately $1.7 \mu \mathrm{m}$ in length and $1.26 \mu \mathrm{m}$ in width. The cytoplasm was rich in free ribosomes and endoplasmic reticulum. The nucleus was almost round and about $850 \mathrm{~nm}$ in diameter. Some vegetative stages were very elongated and monokaryotic. No divisions were observed during merogony.

The sporonts were monokaryotic and showed the same structure as the meronts, except for a thick (200 nm) osmiophilic wall (Fig. 7). This wall was formed by a patchy deposition of electron-dense material between the double membrane, which is a duplication of the plasma membrane (Fig. 5). The sporonts were cells of irregular shape, measuring 1.5-3.7 $\times$ 0.8-1.5 $\mu \mathrm{m}$ (Figs. $6,7)$.

\section{Mature spore}

The spores were found singly in their own sporophorous vesicles. They were oval-shaped (Figs. 11, 12) and measured 1.9-2.5 $\times 0.9-1.2 \mu \mathrm{m}$ (fixed). The spore wall exhibited the three layers characteristic of microsporeans and an external envelope, which covered the entire spore and had juxtaposed points within the exospore (Figs. 12, 13). Sometimes this membrane showed, in young spores, a posterior appendix (Fig. 9), which later disappeared. The spore wall was composed with an internal, $6 \mathrm{~nm}$ thick plasma membrane, a translucent endospore layer of variable size $(80-66 \mathrm{~nm})$ and an electron-dense exospore $(10-30 \mathrm{~nm})$. The exospore was covered by a $20-80 \mathrm{~nm}$ thick envelope, which was attached to it in patches. The exospore showed protuberances in both poles, with a length of 60 and $110 \mathrm{~nm}$ in the apical and distal poles, respectively (Figs. 14, 15). Sometimes two spores were temporarily covered with the same membrane (Fig. 8).

The polar filament with a diameter of approximately $82 \mathrm{~nm}$ was wound in 3 to 4 coils around the posterior part of the spore (Fig. 15). The anchoring disc was 230 $\mathrm{nm}$ wide; the polar filament had a diameter of $100 \mathrm{~nm}$ (Fig. 14). The two lamellar layers of the polaroplast occupied one third of the spore. One part consisted of very thin and condensed lamellae laying over wider and less condensed lamellae (Fig. 14). There was a relatively round vacuole at the basal end of the spore (Fig. 12).

Occasionally, large vacuoles containing spores at different stages of degeneration and residual elements were seen between the gut epithelium (Fig. 16). Early developmental stages and mature spores found intracellularly in the gut epithelium were always intact and did not show any degeneration or lytic processes.

The morphological characteristics of the mature spores as seen in our light and transmission electron microscopic studies are shown in Fig 17.

Table 1. Microsporean parasites reported from oligochaete hosts.

\begin{tabular}{|l|l|l|l|}
\hline Microsporean species & Host species & Site of infection & Authority \\
\hline Microsporidium epithelialis & Tubifex sp. & Gut epithelial cells & This study \\
Myxocystis ciliata & Limnodrilus claparedeanus & Coelom & Mrázek 1897 \\
Myxocystis mrazeki & Limnodrilus hoffmeisteri & Coelom & Hesse 1905 \\
Mrazekia caudata & Tubifex tubifex & Lymphocytes & Léger and Hesse 1916 \\
Mrazekia ilyodrili & Lumbriculus variegatus, & Lymphocytes & Jírovec 1936 \\
& Potamothrix moldaviensis & & Jírovec 1936, \\
Mrazekia limnodrili & Limnodrilus sp., Limnodrilus & Lymphocytes & Janiszewska and Kassner 1978 \\
Bacillidium strictum & hoffmeisteri & Lymphocytes & Léger and Hesse 1916 \\
Bacillidium criodrili & Cumbriculus variegatus & Coelom / Nephridia & Jírovec 1936 \\
Bacillidium limnodrili & Limnodrilus claparedeanus & Lymphocytes & Jírovec 1936 \\
Bacillidium haematobium & Limnodrilus hoffmeisteri & Haemolymph & Jírovec 1936 \\
Bacillidium filiferum & Peloscolex ferox/Tubificidae & Pharynx glands & Larsson 1989b \\
Burkea gatesi & Pheretima hawayana, & & Puytorac de and Tourret 1963, \\
Burkea eisenia & Pheretima californica & & Sprague 1977 \\
Jirovecia involuta & Eisenia foetida & Sprague 1977 \\
Jirovecia caudata & Limnodrilus hoffmeisteri & Chloragogen cells & Larsson 1989a \\
Rectispora reticulata & Limnodrilus hoffmeisteri & Coelomocytes & Larsson 1990a \\
Hrabyeia xerkophora & Pomatothrix hammoniensis & Male gonad & Larsson 1990b \\
\hline
\end{tabular}




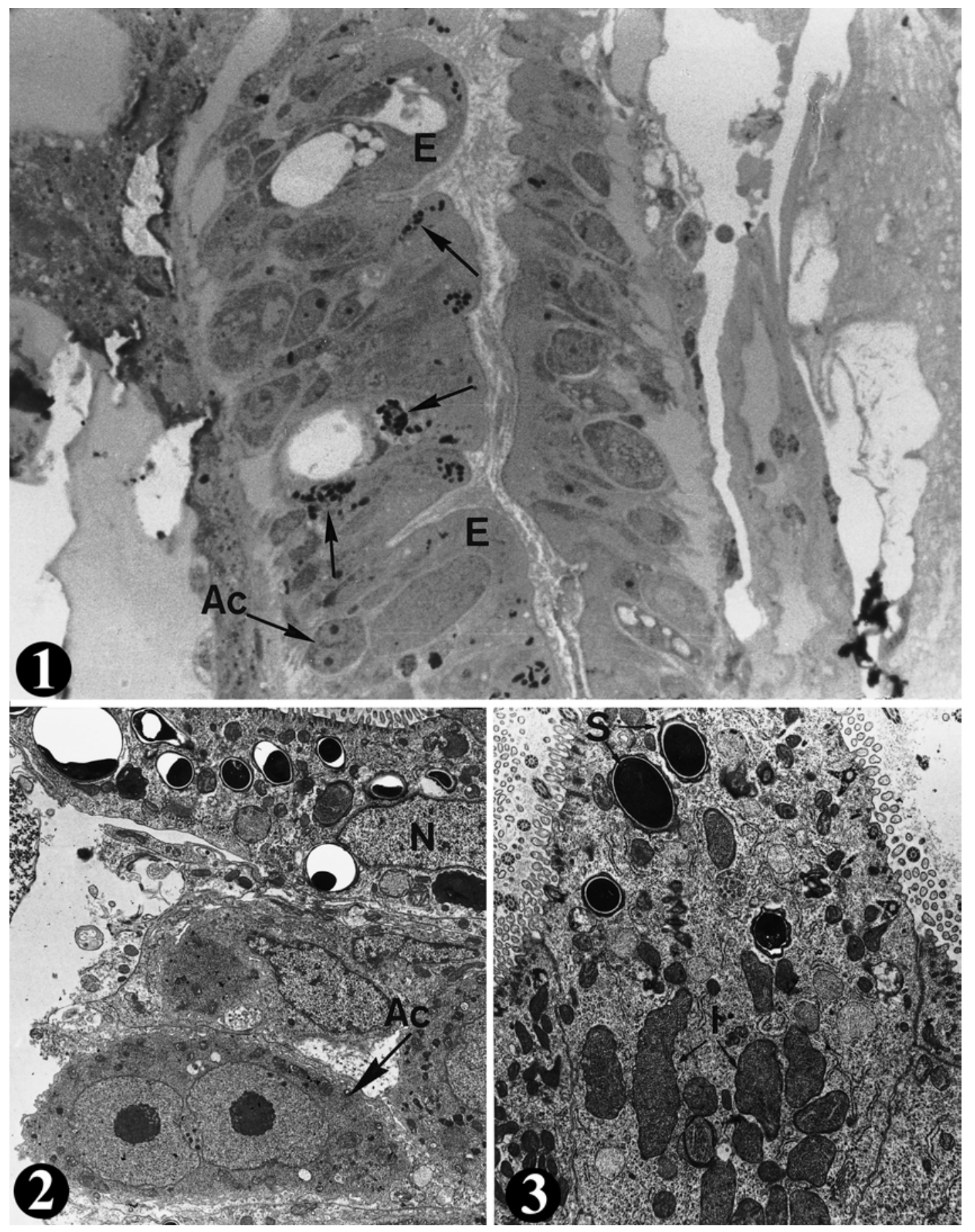

Fig. 1. Longitudinal section through an infected tubificid worm shows a mixed infection with microsporean (arrows) infecting epithelial cells (E) and actinosporean (Ac) between them. Semithin section, toluidine blue. $\times 1200$. Fig. 2. Different stages of the microsporean in the cytoplasm of gut epithelial cell. (N) Host cell nucleus. Binucleate cell stage of the actinosporean (Ac) located intercellularly in the intestine. Electron micrograph. $\times 6300$. Fig. 3. Higher magnification of Fig. 2 shows microsporean immature stages (I) in the basal part of the cell; the mature spores of the microsporean (S) are in the apical part. Electron micrograph. $\times 8800$. 

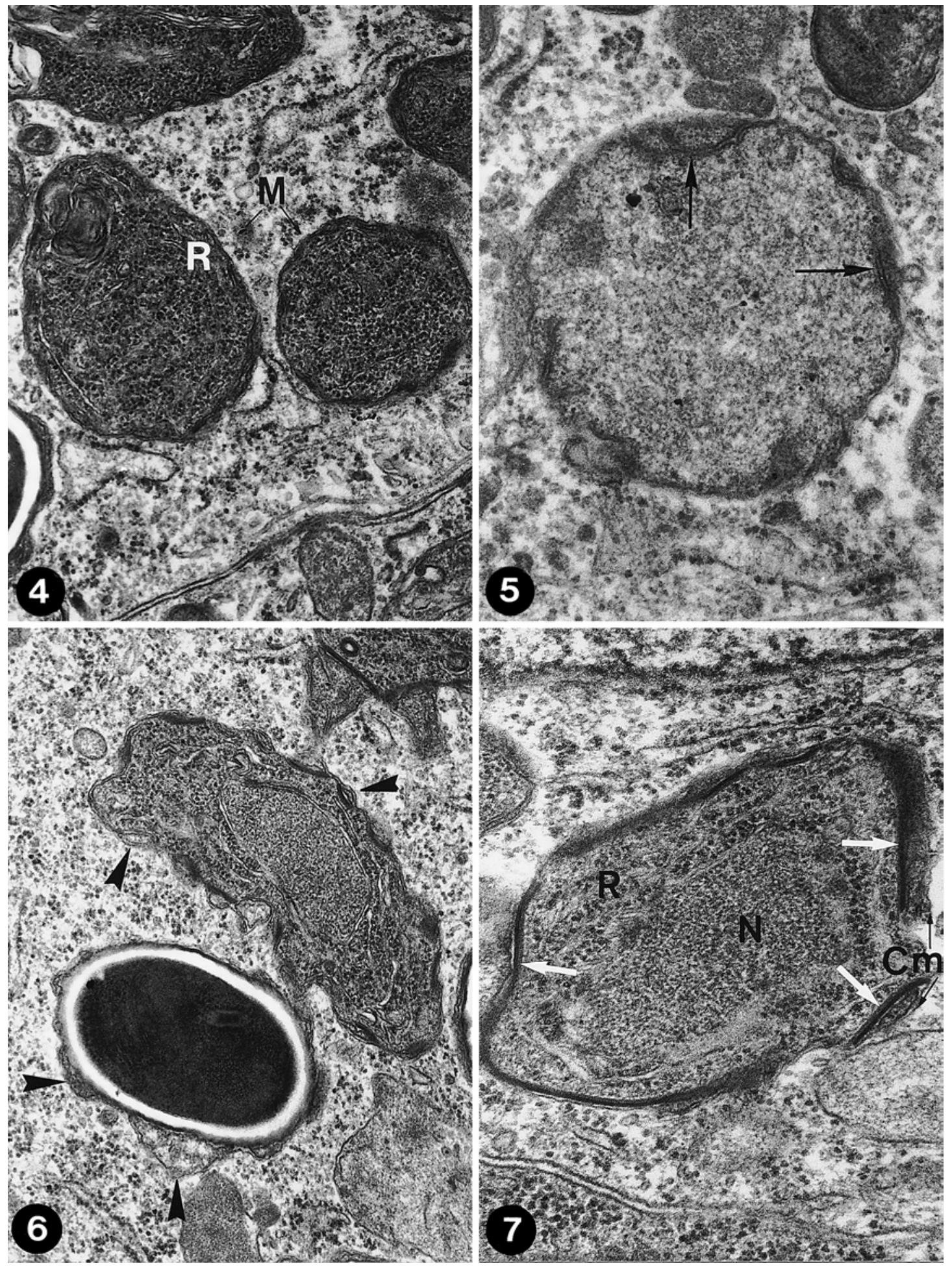

Figs. 4-7. Microsporidium epithelialis sp. n., electron micrographs. Fig. 4. Meronts (M) with cisternae of endoplasmic reticulum (R). $\times 27100$. Fig. 5. Beginning of duplication of the cell membrane of the meront (arrows). $\times 60000$. Fig. 6. Sporont with an electron-dense material, which begins to build the characteristic surface layer (arrowheads). This layer is more developed by the mature spore. $\times 38500$. Fig. 7. Deposition of electron-dense surface material (arrows) inside the cell membrane $(\mathrm{Cm})$. The nucleus $(\mathrm{N})$ is surrounded by cisternae of endoplasmic reticulum $(\mathrm{R}) . \times 60000$. 

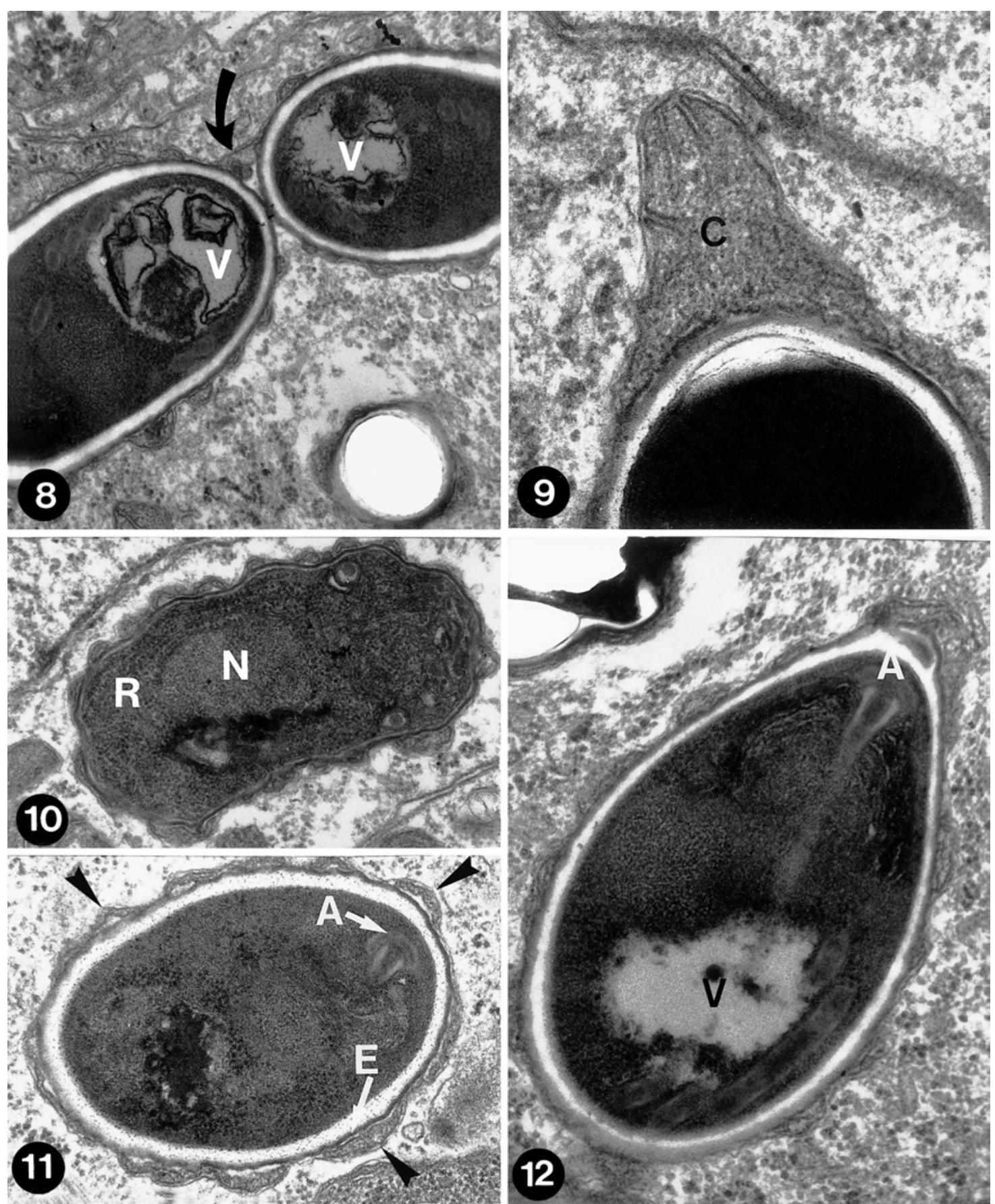

Figs. 8-12. Microsporidium epithelialis sp. n., electron micrographs. Fig. 8. Sporophorous vesicle with two spores. Note the envelope membrane of the sporophorous vesicle (arrow), (V) posterior vacuole. $\times 38500$. Fig. 9. Detail of the caudal appendage (C) of a young spore. $\times 100800$. Fig. 10. Longitudinal section through a sporoblast with a nucleus $(N)$ surrounded by cisternae of endoplasmic reticulum (R). $\times 60000$. Fig. 11. The anchoring apparatus $(A)$ of a maturing spore. The ornamentation of the surface layer (arrows) is formed by and surrounds the exospore $(\mathrm{E}) . \times 60000$. Fig. 12. Spore, with the anchoring disc (A), the attachment of the polar filament, the polaroplast and the posterior vacuole $(\mathrm{V}) . \times 60000$. 

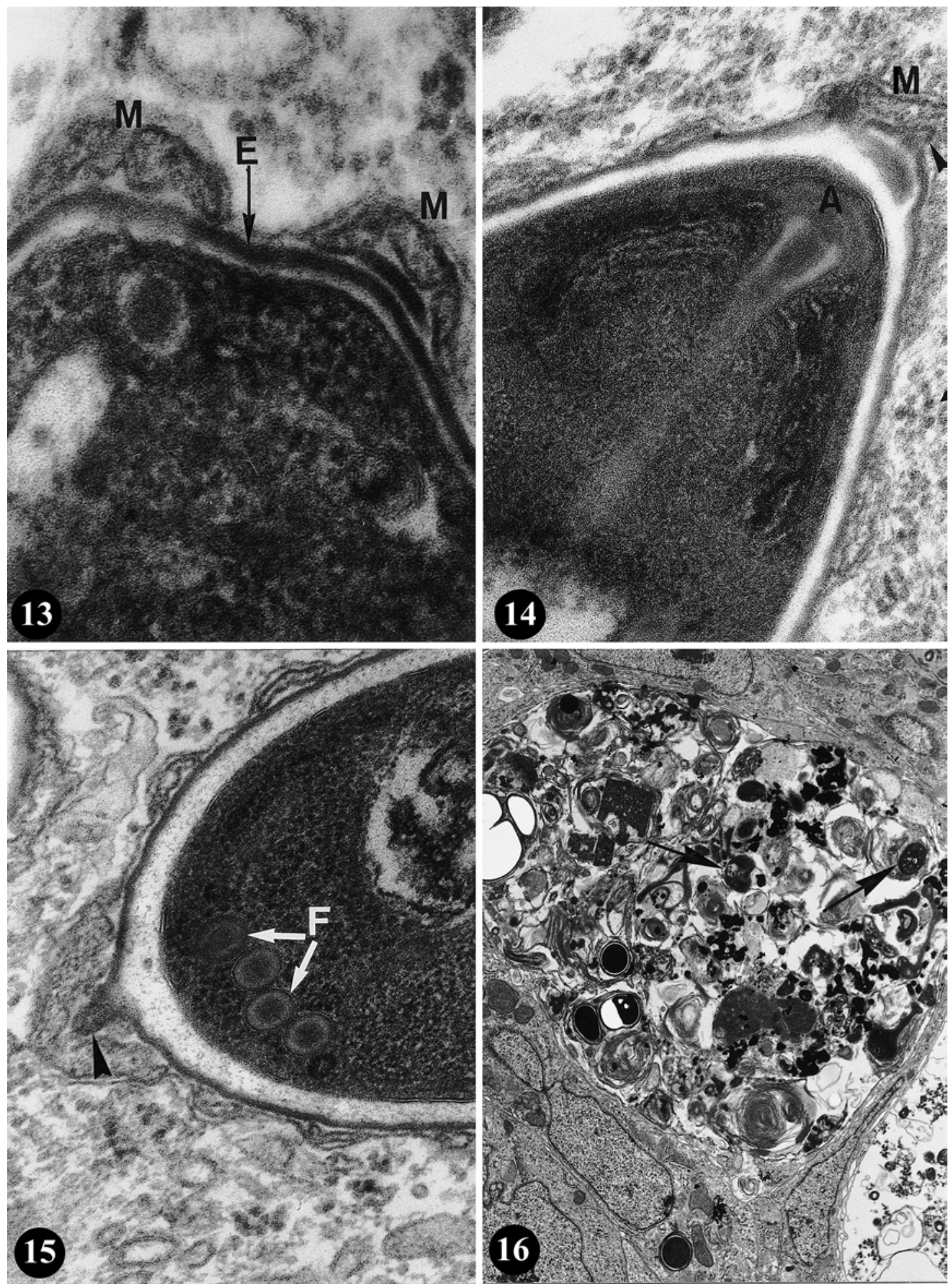

Figs. 13-16. Microsporidium epithelialis sp. n., electron micrographs. Fig. 13. Details of the spore wall. The sporophorous vesicle $(M)$ is attached in patches to the exospore $(E) . \times 166000$. Fig. 14. Mature spore with lamellar polaroplast below the anchoring disc (A). The exospore shows a protuberance (arrowhead), which is covered by the external envelope (M). $\times 100800$. Fig. 15. The exospore shows another protuberance (arrowhead) on the posterior region of a mature spore. Note the four coils of the polar filament $(F) . \times 100800$. Fig. 16. Vacuole of phagocytosis containing spores at different stages of degeneration (arrows). $\times 4000$. 


\section{Taxonomic summary}

Diagnosis. All stages monokaryotic, merogonial stages in direct contact with cytoplasm, sporonts with a thick osmiophilic wall.

Spores. Found singly in a sporophorous vesicle; oviform; dimensions when fixed: 1.9-2.5 $\times$ 0.9-1.2 $\mu \mathrm{m}$; spore wall exhibited three characteristic layers; exospore covered by a thick envelope; sometimes, in young spores, a posterior appendix or protuberances in both poles; sometimes, two spores in the same membrane; polar filament $(82 \mathrm{~nm}$ in diameter) with 3 to 4 coils in a single row; polaroplast with two lamellar layers and in the one third of the spore.

T y p e h o st: Tubifex sp. (Oligochaeta: Tubificidae).

$\mathrm{S}$ i t e of infection: Gut epithelial cells.

T y p e 1 o c a 1 i t y : München, Germany (in live feed for ornamental fish, bought in a commercial pet store).

E t y molog y: The name epithelialis refers to the site of the microsporean in intestinal epithelial cells of the host.

\section{DISCUSSION}

The first description of a microsporean from oligochaetes was that by Mrázek (1897, 1910). Since that time, about 18 microsporean species were reported from oligochaetes, as seen in Table 1 (and some with uncertain descriptions), most of which belong to the family Bacillidiidae Larsson (Larsson 1989a). All species described by Jírovec (1936) in his treatise on microsporeans belong to the genus Mrazekia Léger et Hesse, 1916. This genus shows diplokaryotic stages, has a unique cytology and clearly is not related to the species described here.

The envelope of Microsporidium epithelialis seems to protrude from the exospore, contrary to Hrabyeia xerkophora Lom et Dyková, 1990, a microsporean found in Nais christinae, whose appendix is only an extension of the exospore (Lom and Dyková 1990). The role played by the membrane projections is still unknown, even though Vávra (1968) suggested that they somehow influence the flotation dynamics of the spore in water and the capability of the host to trap it.

According to Larsson (1990a) and Lom and Dyková (1990), the envelope within $H$. xerkophora seems to be thinner and without any organisation, contrary to the species described here which has well-developed ornamentation. It seems to be identical from origin to the ornamentation of Caudospora sp. which, according to Vávra (1968), is represented by projections of the exospore. Our electron microscopic investigations show that, at both anterior and posterior poles, the envelope fits the exospore perfectly and shows protuberances formed as a half-sphere at this level (Fig. 13). Also, the exospore of Lanatospora macrocyclopis Voronin, 1989, that infects the cyclopoid copepod Macrocyclops albidus, seems to be identical to Microsporidium epithelialis. The spore wall consists of a plasmalemma, a thick endospore coat and a complicated exospore having two electron-dense layers and a woolskin-like coat (Voronin 1989).

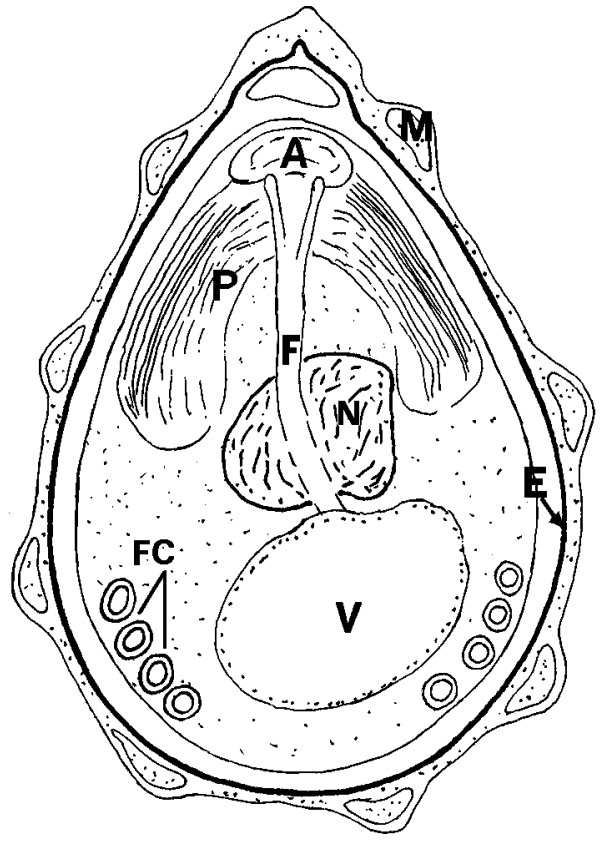

Fig. 17. Diagram of the mature spore of Microsporidium epithelialis sp. n., showing the sporophorous vesicle (M), which surrounds the exospore (E). A - anchoring disc; F polar filament; $\mathrm{P}$ - polaroplast; $\mathrm{V}$ - vacuole; $\mathrm{N}$ - nucleus; FC - coils of the polar tube.

The mature spores of $M$. epithelialis are individually enclosed in a sporophorous vesicle. All previously reported microsporeans that infect oligochaetes are not enclosed in a sporophorous vesicle (Larsson 1989a, b, 1990a, b, Lom and Dyková 1990). The envelope of the spores is similar to that observed in Berwaldia singularis Larsson, 1988, a microsporean that infects the fat body of Daphnia pulex. This microsporean has no appendages and possesses mature spores which are single or paired (Larsson 1988). Codreanu (1961) used the term "diplospore" for the permanent union of two spores in the family Telomyxidae. An adhesive substance, the formation of which seems different from that described in Telomyxa spp. and Berwaldia spp., connects the two spores. In Telomyxa spp., the plasma membrane of the sporont is locally duplicated and electron-dense material is secreted between the membranes. In Berwaldia spp., on the other hand, dense material in several strata is formed outside the plasma membrane where an adhesive substance between the spores is formed (Larsson 1981a). In M. epithelialis, both spores are temporarily connected in the same sporophorous vesicle as in Berwaldia schaefernai Vávra et Larsson, 1994, whose two spores are glued together temporarily or permanently by the substance (Vávra and Larsson 1994). In the family Tuzetiidae, each spore is enclosed in a sporophorous vesicle that divides during sporogony to enclose each sporoblast and spore in a vesicle of its own (Larsson 1981b). It seems probable 
that the diplospore of Telomyxa spp. is a special and highly developed type of sporophorous vesicle with an outer membrane and intersporoblastic secretions forming the equatorial ring to unite and protect the spores (Codreanu and Vávra 1970).

Canning and Sinden (1973) mentioned the presence of a layer of tubules in the space between the membrane and the surface layer of the meront in Nosema algerae. In Berwaldia (Larsson 1981a), Telomyxa (Codreanu and Vávra 1970) and Tuzetia debaisieuxi (Loubés and Maurand 1976), the tubules are observed only within the sporophorous vesicle. We did not notice the presence of tubules in meronts or sporonts of $M$. epithelialis.

We did not observe any division before the formation of spores. However, in Berwaldia singularis, there was no indication that sporonts could differentiate into sporoblasts without undergoing division (Larsson 1981a). In Telomyxa spp., the nuclear division is immediately followed by cytoplasmic division (Codreanu and Vávra 1970).

The lamellar polaroplast, listed as type I according to Larsson's classification (1986), seems to be different from other species encountered in oligochaetes. In Jirovecia spp., it consists of an anterior region with closely packed lamellae and a posterior section with wider lamellae or tubules (Larsson 1989a, 1990a). Although the same composition has been observed in Rectispora reticulata Larsson, 1990, there are only two lamellar parts in Bacillidium filiferum Larsson,1989. No lamellar structure could be observed in Hrabyeia sp. (Lom and Dyková 1990). The polaroplast of Berwaldia singularis is composed of two lamellar parts (Larsson 1981a) and has the same structure in B. schaefernai (Vávra and Larsson 1994). However, the structure of the polaroplast of the Berwaldia spp. is identical to the species studied here. The polar filament in M. epithelialis is distinct, forming three to five coils and is therefore of type I in Loubés's classification (1979). It is shorter than the one found in Berwaldia spp., showing 15 to 18 coils (Vávra and Larsson 1994). In other species infecting oligochaetes, the polar filament has 10 to 13 coils in Rectispora (Larsson 1990b) and between 7 and 10 coils in Hrabyeia (Lom and Dyková 1990).

Despite the difference concerning the ultrastructure of the polaroplast and polar filament, all species infecting oligochaetes are diplokaryotic. In contrast, all developmental stages of $M$. epithelialis are mono- karyotic. This important difference is reinforced by the fact that this microsporean is the only one infecting the gut epithelial cells of oligochaetes (Table 1).

The parasite-host relationship, which results in degeneration of mature spores, has also been observed in Nais christinae (Lom and Dyková 1990). The reaction of the host is accompanied by an enzymatic (lysosomal) degeneration of the mature spores in the digestive vacuoles of neutrophilic leukocytes (Bekhti and Bouix 1985). The vegetative stages and the mature spores are never attacked when they are in the epithelial cells, whereas the vacuoles of phagocytosis containing spores at different stages of decomposition were observed in the interstitial space. The infected cells present no hypertrophy, and no tumours or "xenomas" were observed, contrary to Jirovecia and Hrabyeia infecting oligochaetes and causing xenomas (Lom and Dyková 1990). It is interesting to note that a microsporean and an actinosporean can infect not only the same host (oligochaete) at the same time but also the same organ (intestinal epithelium). The host reaction is oriented only towards the microsporean spores; the actinosporean spores, which develop within the interstitial space, remain unaffected by any host reaction.

In conclusion, the microsporean described here, Microsporidium epithelialis, is the first one found to infect the intestinal epithelium of oligochaetes. Spores are enclosed in a sporophorous vesicle and all developmental stages are monokaryotic. Considering the similarities between $M$. epithelialis and species of the genus Berwaldia Larsson, 1981 such as the sporophorous vesicle enclosing one spore (sometimes two), mononucleate developmental stages, similar polaroplast and ornamentation of the exospore, we are tempted to place this species in the genus Berwaldia. Because we have seen similarities between $M$. epithelialis and members of the family Tuzetiidae Sprague, Tuzet et Maurand, 1977, our study supports the classification of Berwaldia in this family (Vávra and Larsson 1994).

However, it was difficult to place a microsporidium in a genus without knowing how the sporogonial divisions proceed. Moreover, the relationships with the genus Lanatospora Voronin, 1986 are close (all stages are monokaryotic, exospores are similar). We prefer at present to use the name of the collective group Microsporidium as a temporary place for the new form, the expectation of placing it either in Berwaldia or in Lanatospora. We would prefer Berwaldia.

\section{REFERENCES}

BEKHTI N., BOUIX G. 1985: Sur l'évolution des xénomes et le double rôle des polynucléaires neutrophiles dans la microsporidiose á Glugea stephani (Hagenmuller, 1899) chez le flet Platichthys flesus (Linné, 1758). Ann. Parasitol. Hum. Comp. 5: 509-522.

CANNING E.U. 1990: Phylum Microspora. In: L. Margulis, J.O. Corliss, M. Melkonian and D.J. Chapman (Eds.),
Handbook of Protoctista. Jones and Bartlett Publishers, Boston, pp. 53-72.

CANNING E.U, SINDEN R.E. 1973: Ultrastructural observations on the development of Nosema algerae Vávra and Undeen (Microsporida, Nosematidae) in the mosquito Anopheles stephensi Liston. Protistologica 9: 405-415. 
CODREANU R. 1961: Sur la structure bicellulaire des spores de Telomyxa cf. glugeiformis Léger et Hesse, 1910, parasite des nymphes d'Ephemera (France, Roumanie) et les nouveaux sous-ordres des microsporidies, Monocytosporea nov. et Polycytosporea nov. C. R. Acad. Sci. 253: 1613-1615.

CODREANU R., VÁVRA J. 1970: The structure and ultrastructure of the microsporidan Telomyxa glugeiformis Léger and Hesse, 1910, parasite of Ephemera danica (Müll.) nymphs. J. Protozool. 17: 374-384.

HESSE E. 1905: Sur Myxocystis mrazeki Hesse, microsporidie de Limnodrilus hoffmeisteri Clap. C. R. Soc. Biol. Paris 58: $12-13$.

JANISZEWSKA J., KASSNER J. 1978: Tubular aggregates in Mrazekia limnodrili (Microsporida) endoplasmatic reticulum. Zool. Pol. 1: 47-51.

JÍROVEC O. 1936: Zur Kenntnis von in Oligochäten parasitierenden Microsporidien aus der Familie Mrazekidae. Arch. Protistenkd. 87: 314-344.

LARSSON J.I.R. 1981a: A new microsporidium Berwaldia singularis gen. et $\mathrm{sp}$. nov. from Daphnia pulex and a survey of microsporidia described from Cladocera. Parasitology 83: 325-342.

LARSSON J.I.R. 1981b: The ultrastructure of the spore and sporogonic stages of Telomyxa glugeiformis Léger and Hesse 1910 (Microsporida: Telomyxidae). Zool. Anz. 206: 137-153.

LARSSON J.I.R. 1986: Ultrastructure, function and classification of microsporidia. Progr. Protistol. 1: 325-390.

LARSSON J.I.R. 1988: Identification of microsporidian genera (Protozoa, Microspora) - a guide with comments on the taxonomy. Arch. Protistenkd. 136: 1-37.

LARSSON J.I.R. 1989a: Light and electron microscope studies on Jirovecia involuta sp. nov. (Microspora, Bacillidiidae), a new microsporidian parasite of oligochaetes in Sweden. Eur. J. Protistol. 25: 172-181.

LARSSON J.I.R. 1989b: The light and electron microscopic cytology of Bacillidium filiferum sp. n. (Microspora, Bacillidiidae). Arch. Protistenkd. 137: 345-355.

LARSSON J.I.R. 1990a: On the cytology of Jirovecia caudata (Léger and Hesse, 1916) (Microspora, Bacillidiidae). Eur. J. Protistol. 25: 321-330.

LARSSON J.I.R. 1990b: Rectispora reticulata gen. et sp. n. (Microspora, Bacillidiidae), a new microsporidian parasite of Pomatothrix hammoniensis (Michaelsen, 1901) (Oligochaeta, Tubificidae). Eur. J. Protistol. 26: 55-64.

LARSSON J.I.R. 1992: The ultrastructural cytology of Bacillidium strictum (Léger and Hesse, 1916) Jírovec,
1931 (Microspora, Bacillidiidae). Eur. J. Protistol. 28: 175-183.

LÉGER L., HESSE E. 1916: Mrazekia, genre nouveau de Microsporidies à spores tubuleuses. C. R. Soc. Biol. Paris 79: 345-348.

LOM J., DYKOVÁ I. 1990: Hrabyeia xerkophora n. gen. n. sp., a new microsporidian with tailed spores from the oligochaete Nais christinae Kasparzak, 1973. Eur. J. Protistol. 25: 243-248.

LOUBÉS C. 1979: Ultrastructure, sexualité, dimorphisme sporogonique des microsporidioses (Protozoaires). Indices taxonomiques et biologiques. Thèse, Académie de Montpellier. Université des Sciences et Techniques du Languedoc, $86 \mathrm{pp}$.

LOUBÉS C., MAURAND J. 1976: Étude ultrastructurale de Pleistophora debaisieuxi Jirovec, 1943 (microsporidia): son transfert dans le genre Tuzetia Maurand, Fize, Michel et Fenwick, 1971 et remarques sur la structure et la genèse du filament polaire. Protistologica 4: 577-591.

MRÁZEK A. 1897: Über eine neue Sporozoenform aus Limnodrilus. Sitzungsber. Böhm. Ges. Wiss. Math. Naturwiss. Cl. 18: 1-5.

MRÁZEK A. 1910: Sporozoenstudien. Zur Auffassung der Myxocystiden. Arch. Protistenkd. 18: 245-259.

PUYTORAC de P., TOURRET M. 1963: Étude de kystes d'origine parasitaire (Microsporidie ou Grégarine) sur la paroi interne du corps de vers Megascolecidae. Ann. Parasitol. Hum. Comp. 38: 861-874.

SPRAGUE V. 1977: Systematics of the Microsporidia. In: L.A. Bulla and T.C. Cheng (Eds.), Comparative Pathobiology Vol. 2. Plenum Press, New York and London, 510 pp.

SPRAGUE V., BECNEL J.J., HAZARD E.I. 1992: Taxonomy of the phylum Microspora. Crit. Rev. Microbiol. 18: 285295.

VÁVRA J. 1968: Ultrastructural features of Caudospora simulii Weiser (Protozoa, Microsporidia). Folia Parasitol. 15: 1-9.

VÁVRA J., LARSSON J.I.R. 1994: Berwaldia schaefernai (Jírovec, 1937) comb. n. (Protozoa, Microsporida), fine structure, life cycle, and relationship to Berwaldia singularis Larsson, 1981. Eur. J. Protistol. 30: 45-54.

VORONIN V.N. 1989: The ultrastructure of Lanatospora macrocyclopis (Protozoa Microsporidia) from the cyclop Macrocyclops albidus (Jur.) (Crustacea Copepoda). Arch. Protistenkd. 137: 357-366.

Accepted 18 April 2000 